用いて，受発注業務の省力化と迅速化が計画さ れており，病院を含めてソースマーキングで統 一されたバーュードで利用できるよらになれば， 病院におけるラベル貼りやュード管理などの問 題点は一挙に解決することになる（図 4).

も5 1 つの問題は, バーュードラベルが貼付 できない医療材料の商品識別マーキング方法で ある。現在，高額の医療材料や注射薬，錠剤な どを中心に病院で扱われる医療材料の約 3 割近 くがそれに該当するものと考えられる。

著者は, 新しい医療材料のマーキング方法と して, $3 \mathrm{~mm}$ 角程度のスペースに最大 2000 byte の情報量が登録できる 2 次元データュードの利 用を提唱し，2次元データュード自動読み取り 装置の開発も実用レベルになっだ)。このマー キングは，バーュードと競合するものではなく， 同じソースマーキングのコード体系で現場ニズに合わせて使用されることが望ましいと考え ている(図 5 ).

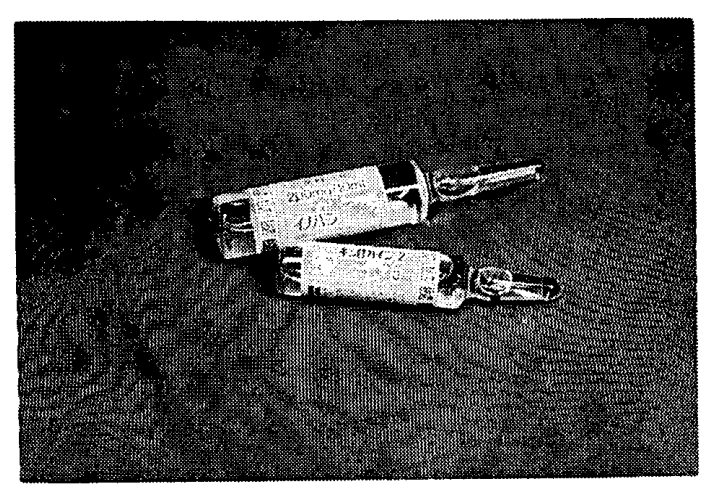

図 5 注射薬に 2 次元データコード表示の試み

近年, 米国の大手医薬品製造メーカーは，2 次元データコードを医薬品にマーキングし, 品 質管理や物流管理に役立てることを計画してい る.

\section{0. まとめ}

今回，病院物流システムを導入するための基 本的事項と今後の問題点について述べた.

病院物流システムは, 病院はもちろん医療業 界全体の今後の展開に大きく影響するところで あることは，医薬品の物流 VANの事例からも 明らかである。

今後, ソースマーキングによるバーコードの 導入は，開かれた病院として医療材料管理シス テムがさらに業界物流ンステムの中で機能する ための要因であり，業界努力による標準化の実 施を望みたい。

最後に本論文は，平成 7 年 10 月に岡山市（テ クノサポート岡山）で開催された日本医科器械 学会主催第 6 回医用器材研究会の講演要旨であ りこご指名くださいました本研究会会長の新太 喜治先生および座長の労をお取り下さいました 加見谷將人先生に深謝致し军寸。

\section{参考 文 献}

1）酒井順哉：病院の物流管理にお㚈る医療情報シ ステムの役割，病院，1992，51(9)，794-799.

2）酒井順哉：病院物流システム構築の基本的な考 方方 在庫管理吕ら物流管理へ向けて, 新医療, 1993, No. 222, 102-106.

3）酒井順哉：医療に打けるバーュード物品管理の 有効利用，月刊バーコード，1991，4(4)，33-37.

4）酒井順哉：ペーパーレス指向と物流システム, 病院設備, 1992, 34(2), 105-110.

5) 酒井順哉, 加藤岡信一, 他： 2 次元データュー ド自動読又取り装置の開発に関する基礎的研究, 手術医学，1995，16(1)，133-136.

\title{
訂正とお詫び
}

本誌第 66 巻 2 号 46 (8) ページの記事の中で, 日本医科器械学会 職業感染対策委員会委員の名前に「副委員長 大久保 憲」が洩れて いましたので，訂正すると共に関係者にお拕びいたします。

(編集部) 